\title{
In vitro Evaluation of Botanical Extract, Bioagents and Fungicides against Purple Blotch Diseases of Bunch Onion in Bangladesh
}

\author{
S M Mustafijur Rahman, Sikder Md. Maniruzzaman*, Shohana Nusrat, Abul Khair \\ Department of Botany, Jahangirnagar University, Bangladesh
}

Copyright $(\mathcal{C} 2015$ by authors, all rights reserved. Authors agree that this article remains permanently open access under the terms of the Creative Commons Attribution License 4.0 International License

\begin{abstract}
The experiment was carried out to survey for incidence and prevalence of purple blotch disease which ranged from 30.49 to 51.76 percent. Isolation, identification of pathogen and determination of pathogenicity were conducted as well; In-vitro evaluation of some botanical extracts, some commercial fungicides and some antagonistic microorganisms against Alternaria porri were performed. At 5 percent concentration of Adhatoda vasica extract showed the maximum of $91.11 \%$ inhibition of mycelial growth of $A$. porri followed by $60 \%$ and $55.33 \%$ of inhibition due to Azadirachta indica and Ocimum sanctum extract respectively. At 10 percent concentration showed similar patterns of mycelial inhibition. The antagonistic effects of four biocontrol agents viz., Trichoderma viride, T. koningii, T. harzianum, Bacillus sp. on mycelia growth of $A$. porri were studied and maximum reduction in colony growth of $A$. porri was observed due to T.viride. All the concentrations $(0.1 \mathrm{~g} / 100 \mathrm{ml} ; 0.2 \mathrm{~g} / 100 \mathrm{ml} ; 0.3 \mathrm{~g} / 100 \mathrm{ml})$ of Bavistin DF and Companion applied fully inhibited the growth of $A$. porri.
\end{abstract}

Keywords Bunch Onion, Purple Blotch, Phytoextract, A. Porri, Bangladesh

\section{Introduction}

Japanese bunch onion or Welsh onion (Allium fistulosum L.) is a kind of perennial onion under the family-Ameryllidaceae [1]. This crop is well suited drained and organic matter enrich soil [2]. Probably originated in north-western China, Bunch onion is quite similar to the onion, also in terms of taste and flavor. The bunch onion consists of hollow leaves ('fistulosum' means 'hollow') and scapes; does not form bulbs. Bangladesh Agricultural Development Corporation (BADC), Kashimpur, Dhaka has introduced bunch onion for seed production. In Kashimpur farm, purple blotch disease is consistently present and known to reduce bunch onion yield and quality (Rahman and
Nahar, unpublished data). Alternaria blight disease is one of the most prominent diseases caused by the genus Alternaria with average yield loss ranges from $32-57 \%$ [3]. Qadri et al., [32] cited that the $62 \%$ disease incidence was found in kharif season (April-October month) while 38\% disease incidence was recorded in rabi season (October-March month) in onion crops. However, Tomaz and Lima [33] observed that onion seed crop and losses of about 80 to $85 \%$ on the crop together with Stemphylum blight. Farmers routinely apply pesticides to bunch onion in attempts to manage the disease. However research on bunch onion production and disease management is lacking in Bangladesh. Among the foliar diseases, purple blotch is one of the most devastating diseases, commonly reported in almost all onion growing areas of the world, which causes heavy loss in onions under field conditions. The disease is however more severe on seed crop as compared to bulb crop causing sometimes $100 \%$ loosing of the seed production. The extent of yield loss incurred by the diseases was not well documented; there were evidences of complete damage of a number of onion fields every year. Therefore, appropriate management practice of purple blotch of onion has become an issue in present condition. Present investigations were undertaken with the following objectives: survey for incidence and prevalence of purple blotch disease on bunch onion in Bangladesh Agricultural Development Corporation (BADC), Kashimpur farm, Gazipur, Dhaka, Bangladesh; Isolation, identification and determination of fungal pathogen from the leaf of Bunch onion; in vitro screening of Trichoderma spp., Bacillus sp., botanical extracts, locally available fungicides for the management of the targeted pathogen identified from Bunch onion.

\section{Materials and Methods}

\subsection{Survey for the Incidence of Purple Blotch Disease}

A rowing survey was conducted to evaluate the percent 
disease index of purple blotch disease of bunch onion of Bangladesh Agricultural Development Corporation (BADC), Kashimur, Gazipur, Dhaka during kharif in 2013 when the crop was three months old. In the field, five plots were selected and in each plot 10 plants were randomly examined and disease incidences were scored by using $0-5$ scale as given by Sharma [34]. Percent disease index (PDI) was assessed by using the formula followed by Wheeler [4].

\subsection{Collection, Isolation and Identification of the Pathogen and Pathogenecity}

The leaves of bunch onion (Allium fistulosum) showing typical symptoms of the purple blotch disease were collected from BADC, Kashimpur, Gzipur, Dhaka field, during May, 2013. The standard tissue isolation technique was followed to isolate the pathogen. Dilute spore suspension was prepared; spreader on agar surface and incubated at $27 \pm 2^{\circ} \mathrm{C}$; single spore was isolated and used for morphological characterization to identify the pathogen as compared with those of the standard measurements provided by Ellis [5].Pathogenecity test of the isolated fungi was carried out as according to Koch postulates.

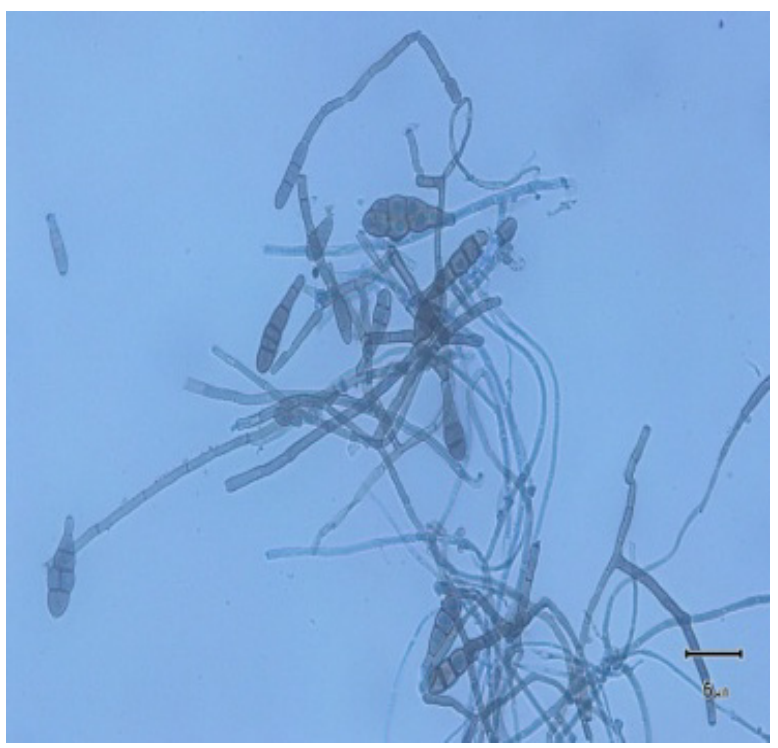

Picture 1. Microscopic view of Alternaria porri (magnification $10 \times 40 \mathrm{X}$ )

\subsection{In vitro Evaluation of Botanical Extracts on the Mycelial Growth of A.porri}

Eight plants known to have medicinal activity, Azadirchta indica, Adhatoda vasica, Datura metal, Ocimum sanctum, Calotropis procera, Annona reticulata, Spilenthis acmela, and Lawsonia inermis were collected from their natural habitats from different location of Jahangirnagar University and Tala Upozilla of Satkhira district, Bangladesh.

The plants parts were dried at room temperature as well as in woven at $70^{\circ} \mathrm{C}$ for $4-5$ hours. The dried plant parts were powdered and soaked in $70 \%$ hydromethanol at $25^{\circ} \mathrm{C}$ for seven days. The mixture was shaken at 200 revolutions per minute (rpm) for 2 hours followed by centrifugation at 4000 rpm for 20 minutes at $4^{\circ} \mathrm{C}$. The supernatant was filtered through Whatman No.4 filter paper and then the methanol was evaporated using rotary evaporator, and finally the extracts were preserved. The effect of plant extracts on the radial growth of Alternaria porri was determined on PDA medium.

\subsection{Invitro Evaluation of Antagonistic Microorganisms against $A$.porri}

Theantagonistic effect of different bio-control agents-Trichoderma harzianum, T. viride, T. koningii and Bacillus sp. were evaluated against $A$. porri by dual culture technique.

\subsection{In vitro Evaluation of Fungicides on Mycelial Growth of A.porri}

Six fungicides viz. Indofil M-45 (Mancozeb 75\% WP), Ashamil-72 (Mancozeb 64\% + Metalaxyl 8\%), Bavistin DF (Carbendazim 50\%), Companion (Mancozeb 63\% + Carbendazim 12\%), Metataf (Metalaxyl), and Copper oxychloride were tested in vitro to evaluate their effect on colony growth by Poison food technique given by Dhingra and Sinclair [6].

\subsection{Data Collection and Statistical Analysis}

After 7 days of incubation, inhibition of radial growth was computed based on colony diameter using the formula provided by Morton and Strouble [7]. Statistical package SPSS-18 was used to analyze the data generated in the experiment.

\section{Results and Discussion}

\subsection{Survey for the Prevalence of Purple Blotch of Bunch Onion}

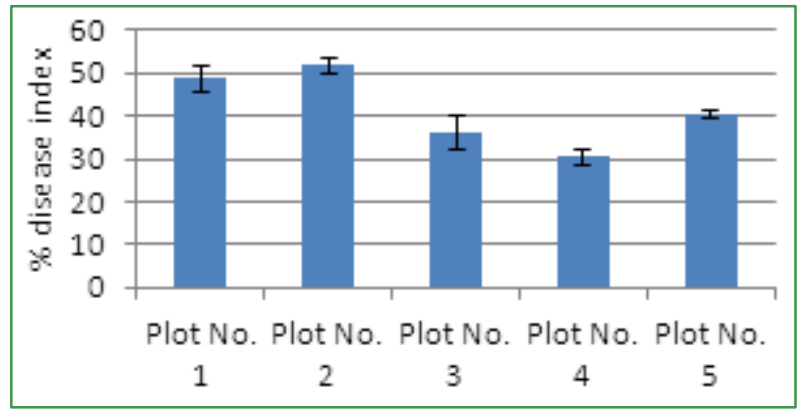

Figure 1. Survey for severity of purple blotch disease of bunch onion in studied field (Value indicated mean \pm Standard error).

It revealed that the prevalence of this disease varied from plot to plot depending on the pathogen attack (Figure 1). Among the plot surveyed, the severity of disease was found 
more in plot number $2(51.76 \%)$ and less in plot number 4 $(30.49 \%)$, indicating that this purple blotch disease was not consistent in all plot studied. This disease was severe in plot number 2 and least in plot number 4 . This could be due to favorable environmental conditions and initial inoculum prevailed which might have helped in the rapid development of the disease.

\subsection{Isolation and Test of Pathogenecity}

Isolation of the pathogen was made from onion leaves and stalks showing typical symptoms of the disease. The pure culture of the studied fungus was obtained after 8 days of inoculation which showed distinct whitish growth at initial stage which turned to ash gray in colourlater on. For proving pathogenicity on host, after 10 days of artificially spread of the pathogens on the leaves of onion plants, the leaves exhibited typical symptoms like purplish spots. Re-iosolation of the pathogens from leaves and the morphological characteristics of the re-isolated organisms was compared with previously obtained original culture of the pathogen and found similar in all respects. Therefore, the causal agents of the disease were confirmed as Alternaria porri (Ellis) Cif. Similar symptoms on bunch onion leaf by $A$. porri were also reported by Agale et al., [28] .

\subsection{In vitro Evaluation of Botanical Extracts on Mycelial Growth of $A$. porri}

The efficacy of eight botanical extracts against A.porri at different concentrations and data of plant extracts on the growth of $A$. porri have been presented in Figure 2. The data revealed that significant reduction in growth of $A$. porri was observed in respect of all the plant extracts tested. Results indicated that the extracts of Adhatoda vasica at $5 \%$ and $10 \%$ concentration caused significantly maximum inhibition of mycelia growth $(91.11 \%)$ and $(95.55 \%)$ of A.porri and minimum inhibition of mycelia growth at $5 \%$ and $10 \%$ concentration $(33.33 \%)$ and $(43.94 \%)$ was recorded with extract of Spilenthis acmela respectively. The inhibition level was high with increasing concentration of the plant extract. Control of fungal pathogens with plant extracts was an effective and safe approach which is of eco-friendly nature. Mycelial growth of Alternaria porri were effectively controlled by leaf extracts of Calotropis procera and Ocmium sanctum respectively [29]. Misra and Gupta [17] cited that $10 \%$ conc. of clove extracts of Allium sativum and Aloe vera showed the maximum inhibition of growth (58.05 and $53.5 \%$ ) of $A$. porri respectively. Present results is consistent with Sobhy et al. [19] who observed 74.4 and $70 \%$ of purple blotch disease reduction after the application of aqueous extract of Datura stramonium and Azadirachta indica under greenhouse condition. Results were found recognizant with previous findings of Hassanein et al., [21] who observed completely suppression of mycelia growth of Alternaria solani on PDA under in vitro due to Azadirachta indica. Chethana et al., [16] found cent per cent inhibition of mycelial growth of $A$. porri by $20 \%$ plant fresh aqueous extract of garlic. More or less similar results on antifungal activity of aqueous extracts of different botanicals have also been reported against onion by Prasad and Barvwal, [8]; Saharan et al., [9]; Vijayalakshmi et al.,[10]; Ramjegathesh et al., [22]; Abdolahi et al., [24]; Swami and Alane [26]; Agale et al., [28]; Singh et al., [30].

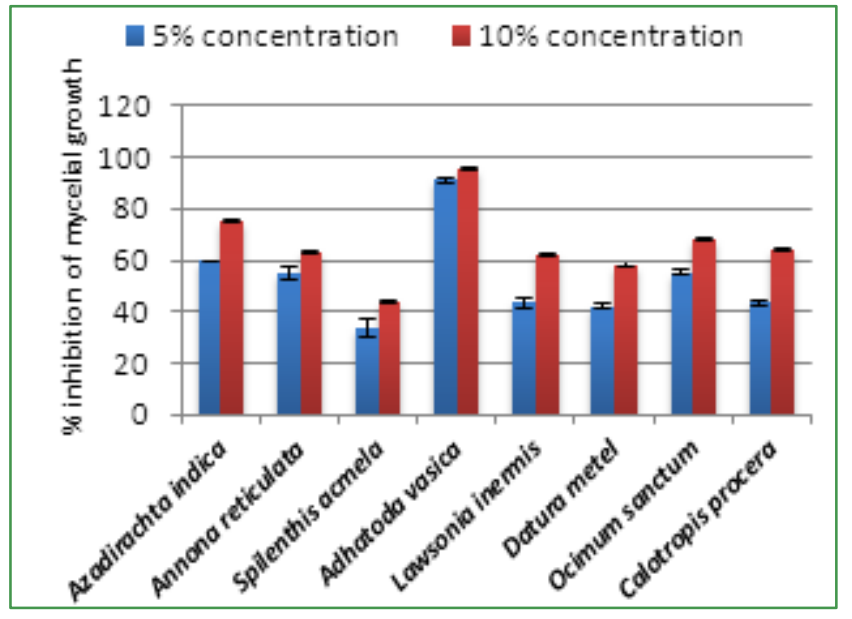

Figure 2. Efficacy of some selected phytoextract on mycelial growth inhibition of $A$. porri(Value indicated mean \pm Standard error).

\subsection{Invitro Evaluation of Antagonistic Microorganisms against $A$.porri}

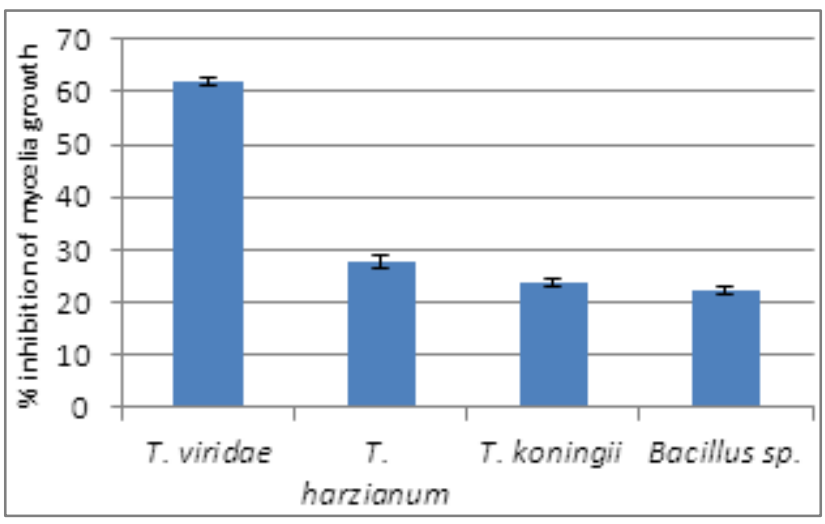

Figure 3. Evaluations of antagonistic microorganisms against A.porri (Value indicated mean \pm Standard error).

Maximum inhibition of colony growth of A.porri was observed by T.viride which was statistically significantly over all the other bioagents tested- T.harzianum, T.koningii and Bacillus sp. (Figure 3). Probable mechanism could be the higher competitive ability, stimulation, and antibiosis by Trichoderma isolate over test pathogen. Similar results were obtained by Misra and Gupta [17-18] who cited that T. viride, T. harzianum, Bacillus were found as effective biocontrol agents against $A$. porri. Kamal et al., [21] reported that application of T. harzianum Th-3013 isolate was resulted the purple blotch disease reduction up to $79.9 \%$ under green house condition. In addition, T. harzianum isolate (Th-3) showed very high level of $A$. porri disease reduction and 
growth promotion of onion under field condition [27]. Kaki et al., [23] found Bacillus isolates as potential biocontrol agents against Alternaria alternata. Similar findings wherein antagonistic effect of Trichoderma spp. against different Alternaria species was previously cited by Amaresh [11]; Savitha [12]; Rao [13]; Gayatri and Madhuri [31].

\subsection{In vitro Evaluation of Fungicides on the Mycelial Growth of A.porri}

All the systemic and nonsystemic fungicides used in the experiment showed significant differences in respect of mycelial growth inhibition of the test pathogen over the untreated control (Figure 4). Completely inhibition of the mycelial growth of A.porri were observed due to all of the three concentration of Bavistin DF and Companion, followed by $90.49 \%$ and $89.02 \%$ inhibition were found by Copper oxychloride and Ashamil respectively. Misra and Gupta [17] reported that $0.2 \%$ conc. of Mancozeb was completely inhibited the growth of $A$. porri. Uddin et al., [20] found that folia application of Dithane M-45 $(0.45 \%)$ or Rovral 50 WP $(0.2 \%)$ were reduced disease incidence $(19.95 \%, 13.63 \%)$ and severity $(38.87 \%, 34.59 \%)$ of purple blotch respectively. Mancozeb 75 WP $(0.25 \%)$ and Copper oxychloride $50 \mathrm{WP}(0.2 \%)$ were showed 79.77 and $76.33 \%$ mycelial inhibition of $A$. porri [28]. The effectiveness of different fungicides against $A$. porri have also been reported by several workers- Sugha [14]; Khosla et al., [15]; Chethana et al., [16]; Mamgain et al., [25]; Gayatri and Madhuri [31].

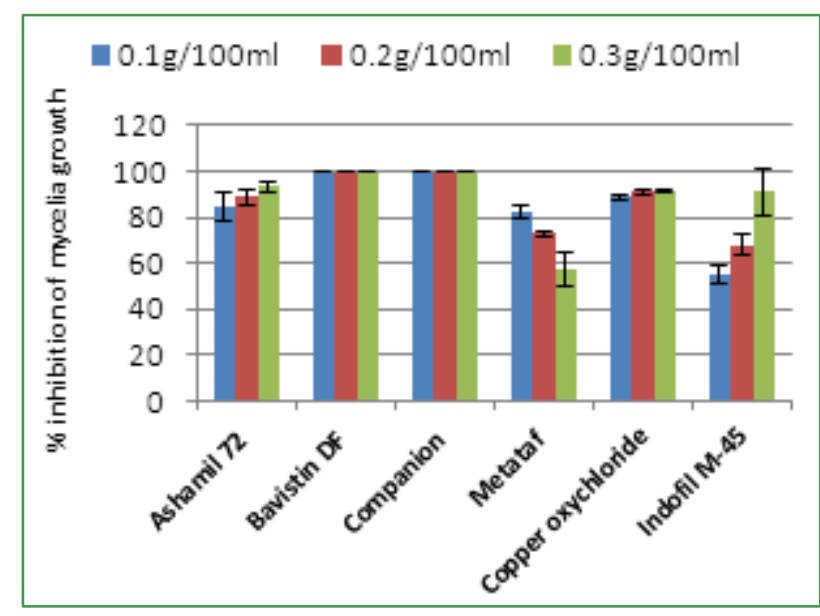

Figure 4. Evaluation of fungicides against mycelial growth of A. porri (Value indicated mean \pm Standard error).

\section{Conclusions}

Among the bioagents, T. viride was found as more efficacious in inhibiting the mycelial growth of $A$. porri. On the other hand, phytoextracts of Adhatoda vasica showed maximum growth inhibition among the plant extracts. Hence, the study indicated that suitable integration of more efficient eco-friendly treatments like bioagents and botanicals may provide a better management of the purple blotch disease of bunch onion in which bunch onion used as human consumption. However, fungicides also showed excellent efficacy against the purple blotch disease, limited use of fungicides for seed production of bunch onion could be used to prevent greater yield losses of the crop.

\section{REFERENCES}

[1] R.M. Fritsch, N. Friesen. Evolution, Domestication, and Taxonomy.In H.D. Rabinowitch and L. Currah, eds. Allium Crop Science: Recent Advances, CABI Publishing, Wallingford, UK, 2002.

[2] W. Maryati, S. Isnaini. Response of welsh onion to various rates of compost application, Journal of Agrivigor, 10(3): 214-221, 2011.

[3] K. L. Conn, J.P. Tewari. Survey of Alternaria blackspot and Sclerotinia stem rot in central Alberta in 1989, Can. Plant Dis. Survey, 70: 66-67, 1990.

[4] B.E.J. Wheeler. An introduction to plant diseases, John Wiley and Sons Ltd., London, 1969.

[5] M. P. Ellis. Dematious Hyphomycetes. Common Wealth Mycological Institute, Kew Surrey, England, 1971.

[6] O.D. Dhingra, J. B. Singlair. Basic plant pathology methods, CRC press, Inc. Boca Raton Florida, USA, 1985.

[7] D. T. Morton, N. H. Strouble. Antagonistic and stimulatory effects of microorganism upon Sclerotium rolfsii, Phytopathology, 45:419-420, 1955.

[8] S. M. Prasad, M. K. Barvwal. Evaluation of plant extracts in management of stemphylium blight of onion, Indian Phytopathology, 57(1):110-111, 2004.

[9] M. S. Saharan, A. K. Sharma, S. Singh. Management of head scab (Fusarium spp.) of Wheat with fungicides, Indian Journal of Agricultural Science, 78(4):328-332, 2008.

[10] M. Vijayalakshmi, M. Madhavi, A. Kavitha. Studies on Alternaria porri (Ellis) Ciferri pathogenic to Onion (Allium cepa L), Archives of Applied Science Research, 4 (1): 1-9, 2012.

[11] Y. S. Amaresh. Epidemiology and management of Alternaria leaf blight and rust of sunflower (Helianthus annuus L.). Ph.D. Thesis, Univ. Agric. Sci., Dharwad, India, 2000.

[12] A. S. Savitha. Variability and toxin studies of Alternaria spp., the incitant of blight of Sesame. M.Sc. (Agri.) Thesis, Univ. Agric. Sci., Dharwad, India, 2004.

[13] M. S. L. Rao. Studies on seed borne fungal disease of sunflower and their management. Ph.D. Thesis, Univ. Agric. Sci., Dharwad, India, 2006.

[14] S. K. Sugha. Management of purple blotch of garlic with fungicides. Indian Journal of Agricultural Science, 65(6):455-458, 1995.

[15] K. Khosla, B. S. Thakur, S. S. Bhardwaj. Chemical management of stemphylium blight of garlic. Plant Disease Research, 22(1):47-51, 2007. 
[16] B.S. Chethana, G. Ganeshan, A. S. Rao, K. Bellishree. In vitro evaluation of plant extracts, bioagents and fungicides against Alternaria porri (Ellis) Cif., causing purple blotch disease of onion, Pest Management in Horticultural Ecosystems, 18 (2): 194-198, 2012.

[17] R.K. Mishra, R.P. Gupta. In vitro evaluation of plant extracts, bio-agents and fungicides against Purple blotch and Stemphylium blight of onion. Seeds, 10(26), 28-42, 2012.

[18] R.K. Mishra, R.P. Gupta. Screening of antagonists against Alternaria porri causing purple blotch in onion, J. Mycol. Plant Pathology, 38(3):645-646, 2008.

[19] A.H. II, Sobhy, K. A. M. Abo-Elyousr, I. R. Abdel-Rahim. Effect of Certain Plant Extracts to Control Purple Blotch Disease of Onion Plants (Allium cepa L.), Upas. J Plant Physiol Pathology, 1:4, 2013.

[20] M. N. Uddin, M.R. Islam, N. Akhtar, A.N. Faruq. Evaluation of fungicides against purple blotch complex of onion (Alternaria porri and Stemphylium botryosum) for seed production, J. agric. educ. technol., 9(1\&2):83-86, 2006.

[21] N.M. Hassanein, M. A. Abu Zeid, K.A. Youssef, D. A. Mahmood. Efficacy of leaf extracts of Neem (Azadirachta indica) and Chinaberry (Melia azedarach) against early blight and wilt disease of tomato, Aust. J. Basic Appl.Sci., 2 (3): 763-77, 2008.

[22] R. Ramjegathesh, E.G. Ebenezar, M. Muthusamy. Management of Onion Leaf Blight by Alternaria alternata (FR.) Keissler by Botanicals and Bio-control Agents, Plant Pathology Journal, 10: 192-196, 2011.

[23] A. A. Kaki, N.K. Chaouche, L. Dehimat, A. Milet, M. Youcef-Ali, M. Ongena, P. Thonart. Biocontrol and plant growth promotion characterization of Bacillus species isolated from Calendula officinalis rhizosphere, Indian Journal of Microbiology, 53(4), 447-452, 2013.

[24] A. Abdolahi, A. Hassani, Y. Ghosta, T. Javadi, M. H. Meshkatalsadat. Essential oils as control agents of postaharvest Alternaria and Penicillium rots on tomato fruits,
Journal of food safety, 30(2), 341-352, 2010.

[25] A. Mamgain, R. Roychowdhury, J. Tah. Alternaria pathogenicity and its strategic controls, Research Journal of Biology, 1, 1-9, 2013.

[26] C. S. Swami, S. K. Alane. Efficacy of some botanicals against seed-borne fungi of green gram (Phaseolus aureus Roxb.), Biosci. Disc, 4(1), 107-110, 2013.

[27] V. Prakasam, P. Sharma. Trichoderma harzianum (Th-3) a potential strain to manage the purple blotch of Onion (Allium cepa L.) caused by Alternaria porri under north Indian plains, Journal of Agricultural Science, 4(10):266, 2012.

[28] R. C. Agale, J.J.Kadam, M.S. Joshi, P.G. Borkar. Symptomatology of purple blotch disease of onion and exploration of fungicides, phytoextract and bio-agents against causal fungus Alternaria porri, History, 11(31), 63-69, 2014.

[29] N. M. Ghangaonkar. Evaluation of phytoextracts for the management of garlic (Allium sativum L.) bulbs fungal pathogens, International Journal of Biological Sciences and Technology, 5(1),1, 2013.

[30] G. Singh, S. Gupta, N. Sharma. in vitro screening of selected plant extracts against Alternaria alternata. Journal of Experimental Biology, 2, 3, 2014.

[31] D. A. Gayatri, V. Madhuri. Seed mycoflora of safflower and its control by using botanicals, bio-agent and fungicides-A review. Int. J. of Appl. Biol, 208-215, 2014.

[32] S. M. H. Qadri, K. S. Srivastava, S.R. Bhope, U.B. Pandey,, P.M. Bhagchan Dani. Fungicidal bioassay against some important pathogens of onion. Pesti., 16: 11-16, 1982.

[33] I. L. Tomaz, A. Lima. An important disease of onion caused by Stemphylium vesicarium (Wallr.) Simmons in Portugal, Hortic. Abst. 58:618, 1988

[34] S.R. Sharma. Effect of fungicidal sprays on purple blotch and bulb yield of onion, Indian Phytopathology, 39(1): 78-82, 1986. 